\title{
A Short Description of some Bible Coins found in Palestine
}

\section{Theodore E. Dowling}

To cite this article: Theodore E. Dowling (1896) A Short Description of some Bible Coins found in Palestine, Palestine Exploration Quarterly, 28:2, 152-160, DOI: 10.1179/peq.1896.28.2.152

To link to this article: http://dx.doi.org/10.1179/peq.1896.28.2.152

曲 Published online: 20 Nov 2013.

Submit your article to this journal ¿

Џ Article views: 6

Q View related articles $\longleftarrow$ 
which acknowledges but "One God, the Father, and One Lord, Jesus Christ" (1 Cor. viii, 5, 6).

The text of the inscription was accurately given in ordinary Roman capitals on p. 130 of the Quarterly Statement, April, 1895, excepting that the name of the emperor is spelt TRAJINI-on the stone it is TrAIANI.

Southampron, October 21st, 1895.

\section{A SHORT DESCRIPTION OF SOME BIBLE COINS. FOUND IN PALESTINE.}

By the Rev. Theodore E. Dowisng.

I. The Shekel, שעקר, corresponding to the word weight.

There is no distinct allusion to the five silver shekels of Simon: Maccabæus (B.c. 141-136) in the New Testament. "The thirty pieces of silver" (St. Matthew xxvi, 15, and xxvii, 3, 5, 6, 9), for which our Lond was betrayed, considered with the parallel passage of Zechariah (xi, 12, 13), suggest this probable reading "thirty shekels of silver"-not actual. shekels, but Syrian tetradrachms, of the same weight. The Revised Version of the New Testament renders the passage "they weighed unto. lim thirty pieces of silver." To this day it is usual in Jerusalem to. examine and test carefully all coins received. Thus a Medjidie (silver) is. not only examined by the eye, but also by noticing its ring on the stone pavement, and English sterling gold is carefully weighed, and returned when defaced. The mention of the weighing of the silver. may indicate a similar state of things, as regards currency, in our LonD's time.

The first distinct allusion to the earliest native Jewish coinage is found in the Apocrypha. There are frequent references to the shekel in the Old Testament, but on'y as a certain weight of silver, not as a stamped coin.

Antiochus VII (Euergetes, Sidetes), famous for his siege and capture of Jerusalem, B.c. 133, "gave" Simon Maccabæus, the brother of the celebrated Judas, "priest and prince of the Jews," "leave to coin money for thy country with thine own stamp" (1 Maccabees xv, 6) in November, B.c. 139.

"The Shekel of the Sanctuary," or "Holy Shekel" was probably the normal weight, and preserved in the Temple.

Its value was about two shillings and eightpence of English money. The average shekel, found in Judæa, weighs between 200 and 220 grains, troy weight. The silver shekel and half-shekel were struck on the Phœnician standard. 
The cup (obv.) represents the pot of manna (Exodus xvi, 33), and the central device (rev.), Aaron's rod that budded (Numbers xvii, 8). No heads or busts are found on the obverse side of strictly Jewish coins.

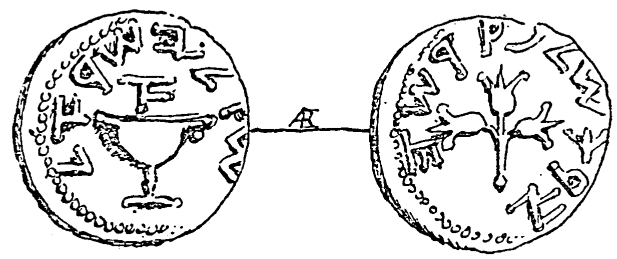

Shekel of the first official year of Simon Maccabæus, B.c. 141-140.

Obverse.-Shekel Isráel, "Shekel of Israel." A cup or chalice. On either side, a pellet. Above, an Aleph, i.e., the numeral letter 1.

Reverse.-Jerushalem Kedoshah, "Jerusalem the Holy." Central derice, Aaron's Rod.

\section{The HaLf-Shekex, בקע, Bekah.}

"And when they were come to Capernaum, they that received the halfshekel (Greek, didrachma) came to Peter, and said, Doth not your master pay the half-shekel? He saith, yea. And when he came into the house, Jesus spake first to him, saying, what thinkest thou, Simon? The kings of the earth, from whom do they receive toll or tribute? from their sons, or from strangers? And when he said, from strangers, Jesus said unto him, therefore the sons are free. But lest we cause them to stumble, go thou to the sea, and cast a hook, and take up the fish that first cometh up; and when thou hast opened his mouth, thou shalt find a shekel (Greek, stater); that take, and give unto them for me and thee." (St. Matthew xvii, 24 to end, Revised Version.)

The annual tax of the half-shekel was, in the course of time, demanded of every free-born adult Jew of the age of twenty years, but under fifty, for the support of the Temple worship. Priests and women were exempt, but not paupers. It was called Atonement or Ransom Money of the LoRD. This Temple poll-tax was levied, and willingly paid, between the 15th and 25th of the month Adar (March-April) at the time of the Passover, of each year. ${ }^{1}$

1 "What must have appealed to every one in the land was the appearance of the 'money-changers' (Shalehanim), who opened their stalls in every countrytown on the 15tb of Adar (just a month before the feast). They were, no doubt, regularly accredited and duly authorised. . . . From this tax many of the priests-to the chagrin of the Rabbis-claimed exemption on the ingenious plea that, in Leviticus vi, 23 (A.V.), every offering of a priest was ordered to be burnt, and not eaten; while from the Temple-tribute such offerings were paid for as the two wave loaves and the shewbread, which were afterwards eaten by priests. Hence, it was argued, their payment of Temple-tribute would have been incom- 
The half-shekel was the Old Testament sacred tribute (2 Chronicles xxiv, 4-15).

The Jews, in their poverty, after the Babylonian Captivity " charged" themselves "yearly with the third part of a shekel for the service of the House of GoD" (Nehemiah $x, 32,33$ ). This ordinance of Nehemiah survived in the time of our SAVIOUR, when the prosperity of the Jews enabled them to return to the original command :- "A bekah for every man, that is, half a shekel, after the shekel of the sanctuary." (Exodus xxxviii, 26.) $)^{1}$

At Capernaum, Simon Peter is asked: "Doth your master yay tribute?" (i.e., the half-shekel). He is sent to the Lake to find "a piece of money" (a silver stater), the exact sum being named by St. Matthew. The instructions are: "that take, and give unto them for Me and thee." In other words, thou shalt find a shekel, the authorised tribute for two souls-neither more nor less-that take, and give unto them (the Jewish Collectors) "for Me and thee." No one except our Lond ever paid the whole shekel. It was illegal. ${ }^{2}$ Each man must pay his own half-shekel, year after year. But our Savioun paid the whole

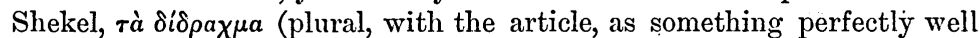
known). Shekels, half-shekels, and copper quarter-shekels had become scarce, not being re-struck after the Maccabæan rule. The silver currency of Palestine in our LoRD's day consisted of tetradrachms of Phœnician and Syrian cities. The Stater of St. Matthew was therefore a silver Tetradrachm, which was of the same value as two half-shekels.

patible with Leviticus vi, 23 ! . . . When it is remembered that, besides strictly Palestinian silver and especially copper coin, Persian, Tyrian, Syrian, Egyptian, Grecian, and Roman were circulated in the country, it will be understood what work these 'money-changers' must have bad. From the 15th to the 25th Adar they had stalls in every country-town. On the latter date, which must, therefore, be considered as marking the first arrivals of festive pilgrims in the City, the stalls in the country were closed and the money-changers henceforth sat within the precincts of the Temple. All who refusea to pay the Temple-tribute (except priests) were liable to distraint of their goods." Edersheim's "Life and Times of Jesus the Messiah," vol. i, ch. v, pp. 367-8. "The official moneychangers for a fixed discount changed all foreign coins into those of the Sanctuary." Ibid., vol. i, ch. i, p. 114.

1 "One of the 'thirteen trumpets' in the Temple, into which contributions were cast, was destined for the shekels of the current, and another for those of the preceding year. These Temple contributions were in the first place deroted to the purchase of all public sacrifices, i.e., for those which were offered in the name of the whole congregation of Israel, such as the morning and evening sacrifices." .... "It seems a terrible irony of judgment when Vespasian ordered, after the destruction of the Temple, that this tribute should henceforth be paid for the rebuilding of Jupiter Capitolinus." Josephus, "Wars of the Jews," book vii, ch. vi, 6; "The Life and Times of Jesus the Messiah," vol. ii. pp. 111-114.

2 The Silver Sockets, pp. 11-15.-W WALLER. 
The value of the silver half-shekel was about one shilling and fourpence of English money. The average weight of existing coins is 110 grains, troy weight. No gold half-shekels or shekels are known to be in existence. Copper specimens of one-half of a shekel and onequarter of a shekel of the "fourth year" of Simon Maccabæus (B.c. 138-137) are still found in Jerusalem.

The genuine silver half-shekel is a rare coin in Jerusalem. The Fellahin occasionally find specimens of the shekel ("year 3 ") in Judæa, during the ploughing season, but I have only seen four half-shelsels in Palestine-three in Jerusalem and one at Haifa (Galilec). I recognised a false half-shekel (probably a recent Hebron forgery) in an European University Museum in 1894. The Jews in Hebron sadly impose upon the uninitiated tourist in Palestine with their skilful imitations of silver shekels of the "year 2," and "year 3." Dr. Selah Merrill, a late American. Consul in Palestine, told me that in his early days at Jerusalem, false Jewish coins were seldom offered for sale. It may be asked, why are shekels more easily obtained than half-shekels? Perhaps the sacred money of the Temple was nelted down by the Roman conquerors of Jerusalem. Hence their scarcity.

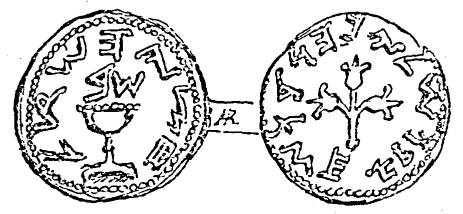

Silver Half-shekel, B.c. 140-139.

Obverse.-Chatzi ha-shekel, "Half-shekel." Pot of manna ornamented with Jewels. Above, the letter Shin with a Beth, i.e., "Year 2."

Reverse.- "Jerusalem the Holy." Central derice, Aaron's Rod.

In June, 1890, a small earthenware jar, containing five shekels and two half-shekels, was brought to the Rev. C. T. Wilson, Jerusalem, by the Church Missionary Society Native Teacher at Bîr ez Zeit, in the Jebel el Kuds (or Jerusalem hills), about one hour and thirty minutes' ride, north-west of Bethel. The story of its discovery, as related to Mr. Wilson, at Bîr ez Zeit, is as follows:-A woman of that Christian village was getting firewood on the site of a ruin known as Khurbet Sîa, about one hour's ride W.N.W. of Bî̀ ez Zeit, close to the rillage of Koba. She saw in the crevice of a rock what she took to be the shell of a species of snail which is eaten by the Fellahin, but, on getting it out, found it was a small jar. Inside this jar were the above-mentioned coins, specimens of which illustrate the text. The coins were in exceptionally good condition, so much so that $\mathrm{Mr}$. Wilson was suspicious of them. However, he ultimately bought the whole of them, with the jar. When found, the jar was full of a fine yellow powder, which the woman emptied out. Mr. Wilson tried afterwards to secure some of this powder, but without success. The jar is $4 \frac{5}{8}$ inches in height, and is perfect. 


\section{The Penny : Greek, onvá $\dot{i}_{i} \iota \nu$; Latin, denarius.}

"Shew me the tribute money. And they brought unto him a penny. And he saith unto them, whose is this image and superscription? they say unto him, Cæsar's" (St. Matthew xxii, 19-22).

"Bring me a penny" (St. Mark xii, 15).

There was a familiar saying of the Rabbis : "Wherever any King's money is current, there that King is lord."

The silver Imperial penny (or Denarius) was the civil tribute money exacted from the Jews in our Savrour's day for the Roman Emperor. 'This tax was specially hateful to the independent and turbulent Galilæans.

Its value was about eightpence half-penny of English money. The Denarius was the ordinary day's wages of the Palestinian peasantry (St. Matthew xx, 2).

The Denarius is mentioned eleven times in the Gospels, and once in the Revelation (vi, 6). It could not have been a coin of the Herods. The head of Herod I is never represented on his twenty copper coins. There is no "image" on any of the ten coins of Herod Archelaus, or on the nine of Herod Antipas.

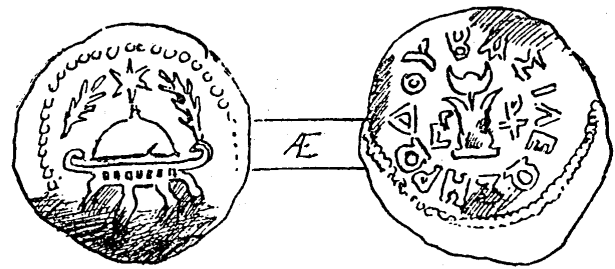

Herod I, surnamed the Great, B.c. 37-4.

Obverse.-A helmet with cheek-pieces. Above, a star. On either side, a palm branch.

Reverse.-BA $\Sigma \mid \wedge \in \Omega \Sigma$ HP $\Omega \Delta \mathrm{OY}$, a tripod, in the field to the left

L. $\Gamma$ (Year 3), and in field to right the monogram $\mathbf{P}$.

Tiberius was the reigning Emperor from A.D. 14 to 37 . The denarii both of this Emperor and of his predecessor Augustus (A.D. 6-14) were unquestionably current in Palestine in our LonD's time. ${ }^{1}$ It is not possible to state positively whether the coin brought to our Saviour bore the similitude of the former or the latter. The probability is that it represented the image of the then reigning Cæsar. In Jerusalem, lowever, the coins of Augustus are, at the present day, more common than those of Tiberius.

1 Three copper coins of the Tetrarch Herod Philip II, son of Herod I (St. Luke iii, 1), B.C. 4-A.D. 34, have the head of Augustus (obv.), and three later coins the head of Tiberius. Specimens, however, are now exceedingly rare in Jerusalem. 
The Denarius is the only Roman silver coin mentioned in the New Testament, and it was the ordinary silver currency of Palestine. Originally, as its name implies, it was a coin equal to ten ases (denis assibus). During the reign of Tiberius the Denarius contained sixty grains troy of silver, and was then considered equivalent to the fourth part of the silver stater, or tetradrachm, or shekel.

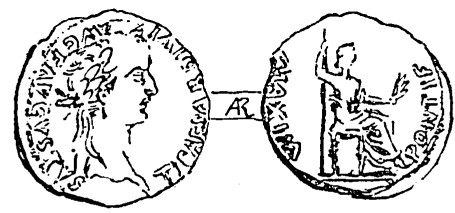

The Penny (or Denarius) of Tiberius, A.D. 14-37.

Obverse.-TI[berius] CAESAR DIVI AUG[usti] F[ilius] AUGUSTUS.

These Denarii are not all from one die, implying different dates. Reverse.-PONTIF[ex] MAXIM[us].

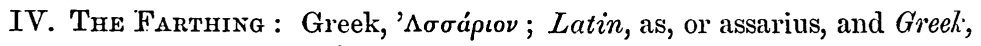

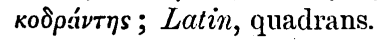

"Are not two sparrows sold for a farthing?" (St. Matthew, x, 29.)

"Are not five sparrows sold for two farthings?" (St. Luke, xii, 6.)

1. The as was (probably) a Roman brass coin, struck at Antioch, in value, in our Lond's time, one-sixteenth of the Denarius, and nearly the size of a halfpenny. Its weight averages 143 grains. At this date no Roman coins were current in Palestine of a smaller value than the $A s$. A lengthened search in Jerusalem has failed in my procuring even the sight of one of these coins.

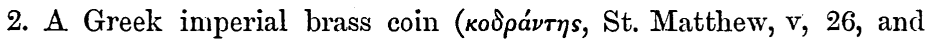
St. Mark, xii, 42) is also rendered in the Authorised Version of the New Testament as a Farthing. I have also failed to obtain a specimen of this coin.

There being much difficulty about the New Testament Farthing, the above paragraph was submitted to a distinguished Scotch numismatist - a specialist in Jewish coinage. His reply is as follows:"I have consulted over a dozen works, and find they are all at sixes and

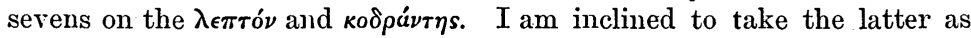
signifying the quadrans. St. Mark, writing, as is supposed, for Roman readers, informs them that a $\lambda \epsilon \pi \tau{ }^{\prime} \nu$ was $=\frac{1}{2}$ quadrans. So that $\mathrm{I}$ am not sure that we need suppose that a coin of the value of the Quadrans is asserted to have been in circulation in Palestine in the first century. There is no mention of such a coin in the Mishna (see 'Schiirer History,' \&c., Div. II, vol. i, p. 40)."

Another numismatist in Galilee has suggested one or other of the small copper coins of the five first Procurators of Judrea, and I am 
inclined to agree with my learned friend, the Rev. J. E. Hanauer, of Jaffa, that this may have been the case.

3. There is a rare coin of Cuponius, the first Procurator. Only one specimen is in my collection. This coin may, therefore, be left out of consideration.

\section{Reigar of Augustus.}

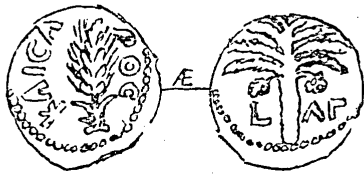

Coponius, First Procurator, A.D. 6-7.

Obverse.-KAICAPOC. An ear of corn.

Reverse.-A palm-tree, from which hang bunches of dates. In field, to right and left, L. $\Lambda \Gamma$ (Year 3i).

2. Marcus Ambivius, Second Procurator, has a coin nearly resembling that of Coponius. It is eisily procurable in Jerusalem.

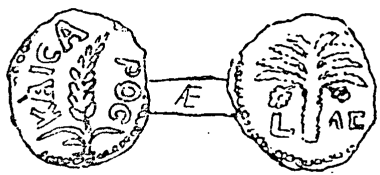

Marcus Ambivius, Second Procurator, A.D. 9-10.

Obverse.-KAICAPOC. An ear of corn.

Reverse. - A paim-tree, from which hang bunches of dates. In field, to right and left, L. $\wedge[$ (Year 36).

3. Three coins are attributed to Annius Rufus, Third Procurator. The first, L. $\triangle \odot$ (A.D. 12-13), and third, L. MA (A.D. 14-15), are stil common, but the second issue, L. M. (A.D. 13-14), is scarce.

\section{Reign of Augustus.}

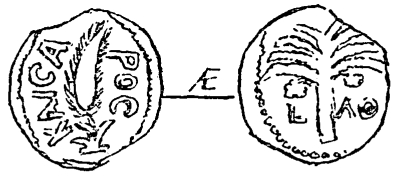

Annius Rufus, Third Procurator, A.D. 12-13.

Obverse.-KAICAPOC. An ear of corn.

Reverse. - A palm-tree, from which hang bunches of dates. In field, to right and left, L. $\wedge \Theta$ (Year 39). 
4. There are at least twelve coins belonging to Valerius Gratus, Fourth Procurator. Only two of these are now frequently found, viz., a coin of the Fifth Year L. E. (A.D. 18-19), and another of the Eleventh Year, L. IA (A.D. 24-25). The interesting specimen of the Fifth Year is reproduced.

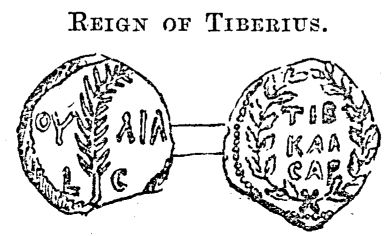

Valerius Gratus, Fourth Procurator, A.D. 18-19.

Obverse.-TIB - KAI - CAP, in three lines within a wreath. Reverse.-1OY-AIA. A palm. In field, to right and left, $L . \in$ (Year 5 ).

5. Five coins are connected with Pontius Pilate, Fifth Procurator. Four of them are common. A specimen of the first known issue, sixteenth year (A.D. 29-30), is given.

Reign of Tiberius.

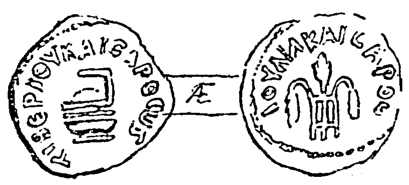

Pontius Pilate, Fifth Procurator, A.D. 29-30.

\section{Obverse.-TIBEPIOY KAICAPOC L. IS (Year 16). Reverse-IOYAIA KAICAPOC. Three ears of corn bound together.}

The obverse side of many of these Procurator coins is officially stamped with the approved KAICAPOC, and the reverse side is frequently either a palm tree or a palm branch.

The coins struck by the Procurators of Judæa seem to have been a local Hebrew currency, with the Roman imprimatur. "We have no King but Cesar!" covered their first century status, at least, barring revolts, when they re-asserted themselves alone.

Do not the dates attached seem to favour either a coin of Marcus Ambivius and Annius Rufus in the reign of Augustus, or a Valerius Gratus and Pontius Pilate in the reign of Tiberius, as the New Testament Farthing? But this section demands a searching investigation, and Dr. Williamson ("The Money of the Bible," p. 66), may well draw attention to "the words which are in the duthorised Version very much mistranslated as farthing." 


\section{The Mrte: Greek, $\lambda \epsilon \pi \tau o ́ \nu ; ~ L a t i n$, minutum.} " $\mathrm{xxi}, 2$.)

"The very last mite." (St. Luke, xii, 59.)

The Widow's Mite was a Jewish coin. Foreign money was not accepted in the Temple. Roman money was exchanged by the moneychangers at their stalls in the Court of the Gentiles. ${ }^{1}$ The Mite was the smallest current Jewish copper coin in the time of our SAvrour. ${ }^{2}$ It was also the smallest Temple contribution, legally admissible. The Mite was (probably) one of the coins-not re-struck- of Alexander Jannæus (B.c. 105-78), or one of the other early Jewish princes.

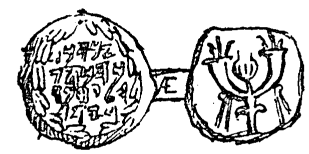

The Mite.

A coin of Alexander Tannæus.

Obverse.- "Jonathan, the High Priest, and the Confederation (or Senate) of the Jews," within a wreath of olive.

Reverse.-Two Cornua-copiæ, between which a poppy-head.

My thanks are due to the Rev. C. T. Wilson, Jerusalem, for the loan of his silver shekel and half-shekel, exceptionally well-preserved specimens ; also to Miss Hussey, of Jerusalem, for supplying the illustrations from my collection of Jewish and Syrian coins ; also to Mr. Madden, for invaluable guidance obtained from his helpful "Coins of the Jews."

1 "Under the Colonnades, which surrounded 'the Court of the Women' ... provision was made for receiving religious and charitable contributions. All along these colonnades were the thirteen trumpet-shaped boxes (Shopharoth). .... These 'trumpets' bore each inscriptions, marking the objects of contribution." Edersheim's "Life and Times of Jesus the Messiah," rol. ii, p. 386.

2 "Simon Maccabæus had copper money coined; the so-called copper shekel, a little more than a penny, and also half and quarter shekels (about a halfpenny and a farthing). His successors coined even smaller copper money. During the whole period from the death of Simon to the last Jewish war no Jewish silver coins issued from the Palestinian mint, but only copper coins. Herzfield suggests that there was sufficient foreign silver coinage circulating in the country, while naturally only a very small amount of foreign copper coins would be brought to Palestine." Edersheim's "Life and Times of Jesus the Messiah," vol. i, ch. v, p. 367 , note. 